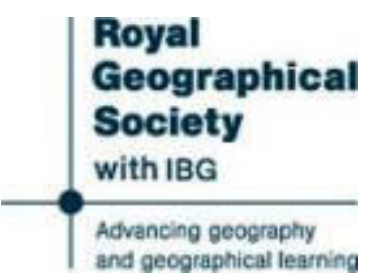

\title{
England and Wales Viewed Geographically
}

Author(s): Hugh Robert Mill

Source: The Geographical Journal, Vol. 24, No. 6 (Dec., 1904), pp. 621-636

Published by: The Royal Geographical Society (with the Institute of British Geographers)

Stable URL: http://www.jstor.org/stable/1776254

Accessed: 26-02-2015 00:10 UTC

Your use of the JSTOR archive indicates your acceptance of the Terms \& Conditions of Use, available at http://www.jstor.org/page/info/about/policies/terms.jsp

JSTOR is a not-for-profit service that helps scholars, researchers, and students discover, use, and build upon a wide range of content in a trusted digital archive. We use information technology and tools to increase productivity and facilitate new forms of scholarship. For more information about JSTOR, please contact support@jstor.org.

The Royal Geographical Society (with the Institute of British Geographers) is collaborating with JSTOR to digitize, preserve and extend access to The Geographical Journal. 


\section{ENGLAND AND WALES VIEWED GEOGRAPHICALLY.*}

\section{By HUGH ROBERT MILL, D.Sc.}

Ir is the causal idea in geography which makes the science rich and full of human interest, and the object of the present article is to indicate, in a particular case, the broad lines along which this idea works, and to give such concrete instances as may help the reader to follow them farther and apply them more completely. In treating England and Wales from the purely geographical standpoint, the aim is thus not to state facts which may be new to the reader, but rather to supply a framework in which the familiar facts fit naturally, and by their placing throw light upon each other and the whole.

Geologists have pointed out that the nature and arrangement of the rocks determine the way in which climatic conditions act upon and shape the land into hill and valley or plain. But this is only the beginning of a vast and complicated system of mutually interacting agencies. The land-forms, produced originally by climatic influences, affect in their turn the incidence of wind and rain so as to give rise to local climates of great interest and importance. Climate and landsurface together affect the distribution of vegetation and the nature of plant associations, and this distribution also reacts upon both the climate and the land-surfac3. All these influences bear upon the distribution of animals, and play their part in deciding the places of human settlement and the lines of human movement, and finally human energy reacts upon every element of the complex geographical environment, and that more effectively than any of the unconscious activities of nature.

The form and elevation of the land-surface are the most important geographical conditions at any particular epoch of time. Although they are constantly changing on account of the action of all the forms of activity which they direct by offering unequal resistance, the process is so slow that, except in a few instances, it is of no importance within the range of human history. Viewed in relation to the vistas of geological time, the hills may be fleeting shadows and the coasts changing forms, but geographically, save for the small exceptions referred to, the hills are eternal and the coasts are boundaries that cannot be passed. The permanence of physical configuration in relation to human history is a fact that should never be lost sight of. It constitutes one of the clearest lines of division separating the fields of geography and geology.

The fundamental conditions of vertical relief and coast-development in England and Wales are shown with beautiful clearness in the map, where they appear alone, on a somewhat small scale it is true, but unobscured by artificial boundary lines or the names of towns or counties.

* To accompany a map embodying the nomenclature of the physical features of England and Wales. Map, p. 708. This map was prepared by Mr. J. G. Bartholomew, 
Strictly speaking, the large island of Great Britain should be described as a single unit, yet it is surprising how distinct the northern and southern portions are, physically as well as historically; and there is no violence done to fact by treating England and Wales by themselves. The coasts are more uniform in outline, less indented, and far less deeply fringed by off-lying islands than those of Scotland; but, as in the northern kingdom, the east coast is simpler and less indented than the west.

From the mouth of the Tweed on the extreme north in lat. $55^{\circ} 48^{\prime}$ to Lizard Head on the extreme south in $49^{\circ} 58^{\prime}$, there is a range of nearly six degrees in latitude; and from Lowestoft in long. $1^{\circ} 56^{\prime} \mathbf{E}$. to Land's End in $5^{\circ} 43^{\prime}$ W., there is a range of $7 \frac{1}{2}$ degrees in longitude, corresponding to a difference of half an hour in time. If the extreme points of the coast were joined by straight lines to form a figure resembling a triangle, but open at the top, the eastern side would measure 348 miles, the southern 316 miles, and the western 354 miles. When, however, allowance is made for the indentations of the actual outline, the east coast is found to measure 640 miles, the south coast 545 miles, and the west coast as much as 1225 riles. If the smallest possible length of coast-line be represented in each case by 1 , the actual length of the east coast would appear as $1 \cdot 8$, of the south coast $1 \cdot 7$, and of the west coast no less than 3.5 ; in other words, the west coast is twice as much indented as the east or south.

The indentations of the coast are sufficiently large and numerous to secure that no point in the whole of England and Wales is more than 75 miles from the se:. The most inland part of the country is a narrow strip stretching from Buckingham to near Birmingham. The narrowness of the southern part of the North Sea and of the eastern end of the English Channel enable the great land mass of the neighbouring continent to influence the climate of a considerable part of the south-east of England, thus extending the area of typically inland country.

The three coasts of England appear even more dissimilar when considered in relation to the land behind them and the sea in front. The unindented east coast borders the Eastern Plain for the whole distance

and the nomenclature upon it originated in a discussion at a meeting of the Research Department of the Royal Geographical Society upon a paper by Dr. H. R. Mill. A sub-committee of the Research Committee, consisting of Mr. G. G. Chisholm, Mr. H. J. Mackinder, and Dr. H. R. Mill, was appointed to suggest a nomenclature for the larger features of the relief of England and Wales, especially for such features as were without definite names for their whole extent. This Committee proposed a series of names, endeavouring to introduce none which were not in harmony with the general character of English place-names. The proposals were discussed in the Research Committee, and remitted to the Council of the Royal Geographical Society, by which, after further discussion and some modification, they were approved. Although the nomenclature proposed by the Committee and approved by the Society is adopted, the article cannot claim to express more than the individual views of the author. 
between the chalk promontories of Flamborough Head and the South Foreland. It is broken by the large and shallow estuaries of the Humber, the Wash, and the Thames. The estuary of the Thames opening opposite the mouths of the Rhine, in a sense made London; but the town has grown to such importance that to the sailor the whole estuary is known as London River, and technically the Port of London includes all the waterways and docks between London Bridge and the Nore. Both the Thames and the Humber early became, and have always cuntinued to be, great centres of maritime trade with the Continent; but the Wash is too shallow for modern ships, and except for Harwich-a ferryport to the Continent-none of the smaller estuaries or coast towns are inore than fishing ports or pleasure resorts. North of Flamborough Head the coast is steeper and higher, the estuaries, though small and narrow, lead into regions of mineral wealth, so that they could be profitably deepened to admit the largest vessels for the export of coal and manufactures of iron and chemicals. Thus the Tees has given rise to the iron-exporting and ship-building ports of Middlesbrough and Hartlepool; the Wear gives access to the great steel-ship building town of Sunderland ; and the narrow estuary of the inky Tyne has become one long seaport for sending out coal, chemicals, and ships and munitions of war from Shields at the mouth to Newcastle at the head of navigation.

The North Sea stretches as a shallow and often a very stormy sheet of water towards the Continent. Depths exceeding 30 fathoms do not occur south of the latitude of Flamborough Head, and the deepest water between any part of the east coast of England and the opposite shore of the Continent reaches 50 fathoms only in one small patch. The floor of the North Sea rises in the centre to a large plateau known as the Dogger Bank, on which the depth varies from 20 to less than 10 fathoms. South of the Dogger, the sea-bed is curiously ridged and furrowed by long banks and "pits" running nearly parallel to the coast, each of which has been discovered and sounded out by the fishermen who have from time immemorial reaped the ever-ripe harvest of the flat-fish of the North Sea. The soles and plaice bred in the shallow water of the Eastern Grounds bordering the continental shore migrate as they approach maturity towards the central and western banks, so that large-sized fish were probably always more numerous off the coast of England than near the Dutch and German ports. In their time one or another of the pits or banks became famous for the abundance or the quality of its fish, and in the days of line-fishing and of trawling smacks, the fishing villages adjacent to these grounds became places of local importance. The introduction of steam trawlers and of steam fish-carriers changed the relation of the east coast fishing grounds and fishing villages. The chief concern being to bring the fish quiokly to the market, the trade has become concentrated to a remarkable extent in the Thames, where the steam carriers, coming direct from the fishing 
fleets at sea, run right up to Billingsgate Market, and at Grimsby, at the Humber mouth, where good dock accommodation and an excellent railway service bring the trawlers of the Northern Grounds into communication with all parts of the country. Hull, Yarmouth, and Lowestoft also derive benefit from the North Sea fisheries, and owe much of their importance to that cause.

Where the North Sea meets an arm of the Atlantic in the Strait of Dover, the narrowing of the dividing sea gives rise to the passenger traffic with the Continent which has been the making of Dover and Folkestone. The strategic as well as the commercial importance of Dcver, commanding as it does the two seas, has justified the enormous expense of constructing a great naval and commercial harbour on one of the most unpromising sites along the whole coast, and has given rise to keen controversy as to the political wisdom of sanctioning attempts to build a bridge or bore a tunnel to overcome the insularity of Britain and give access by rail to foreign countries.

The south coast faces a deeper sea than does the east, but one less adapted for fishing by means of the trawl; and, except in the case of the mackerel, pilchard, and herring fishery of the west, little development has resulted from that industry. The shelter afforded by the Isle of Wight to the channels of Spithead and the Solent, and the depth of Southampton Water, running inland to within two hours by rail of London, have given immense and growing importance to the centre of the south coast. The commercial harbour of Southampton, the port for passenger embarkation to South Africa and by several lines to America, finds its naval counterpart in Portsmouth. The narrowing of the English Channel between the Isle of Wight and Portland Bill on the north, and the peninsula of Brittany on the south, gives occasion to the most westerly line of cross-channel traffic from Weymouth and Southampton to France and the Channel Islands.

The western extremity of the south coast partakes of the general character of the west. Deep inlets running far into the land form magnificent natural harbours, in the finest of which-Plymouth Sound - lie the naval dockyards of Devonport. Here the development of a large trade in the transfer of passengers and mails carried by ocean liners depends only on the ability of the railways to give rapid communication with the great centres of population, and an improved train service has brought Plymouth almost as near London in point of time as Liverpool is.

The west coast opens upon the Atlantic obliquely through St. George's Channel, and for the most part it faces the turbulent Irish sea, the depths of which are similar to those of the English Channel, and greater than those of the North Sea. The edge of the continental shelf with soundings of 100 fathoms runs from Ushant to off the west of Ireland, at right angles to the English and the Bristol Channels, so that vessels 
even in a fog can find soundings and know their position long before there is any danger of running ashore. No other gateway of maritime commerce is so efficiently guarded by Nature against risk of shipwreck. Two important inlets, the large and wide Bristol Channel and the narrow Mersey estuary, run far into the land, one to the south and one to the north of the bold projection of Wales. The Bristol Channel, originally of value as an ocean highway leading to Bristol, has now greater importance from the ready outlet it affords to the coal-shipping ports of Cardiff, Barry, Swansea, and Newport along its northern shore. The Mersey is the chief entrance for American and West African trade to the densely peopled northern industrial area, most of the goods being landed or loaded in the docks of Liverpool and Birkenhead. It is the entrance, also, for the growing traffic by direct steamers through the ship-canal to Manchester.

The block of Wales separating south-western from north-western England runs out into two promontories separated by the wide sweep of Cardigan Bay. The southern promontory is cleft by Milford Haven, a harbour which has lost the advantage of its fine geographical position from the sea on account of its unfortunate geographical position from the land, lying as it does remote from the great centres. The northern promontory is the low island of Anglesey, where Holyhead, being almost in the straight line from London to Dublin, is naturally the chief port for communication with Ireland. Northward of the Mersey the sandy plain of Lancashire fronts a low shore, where a few small ports struggle against great natural difficulties. Barrow, one of the most purely artificial seaports in the country, draws its prosperity from the iron and coal deposits of the margin of the Lake District. The west coast of England terminates in the sandy shallows and treacherous tides of the Solway, an inlet of the sea resembling the Wash in its economic inutility.

The surface of England stands in close relationship to the nature of the underlying rocks, and the influence of the broad geological divisions can be traced through all the geographical distributions. Looked at as a whole, South Britain is divisible into three parts. The Western Division comprises three masses of uplands, all composed of ancient rocks much penetrated by old volcanic outbursts, and each attaining a maximum elevation exceeding 2000 feet above the sea. The Northern mass includes the Cheviots, the Lake District, and the Pennine Chain; the Western consists of Wales and the bordering hill ranges; and the Southern occupies the peninsula of Devon and Cornwall. The Eastern Division corresponds with the region of the Jurassic, Cretaceous, and more recent rocks. Few points within it attain an elevation so great as 1000 feet, and the hills which ridge its surface are for the most part escarpments, steep on one side and gently sloping on the other. The hard ancient rocks, with their treasure of the Coal Measures and their 
volcanic dykes and bosses, are buried far beneath the surface. Between the two divisions the third stretches as a transition zone popularly known in its central part as The Midlands, but that name was not adopted for the map. On the south and east this corresponds with the plain of Lias clay, on the north and west with the plain of the Triassic red rocks separating the groups of the Western Division.

The rivers of England and Wales necessarily radiate from the elevated masses of land and flow across the bordering plains to the sea ; but it is worthy of remark that, with the solitary exception of the Humber, no streams rising in the Western Division cross the Eastern Division on their way to the sea.

The climate of England and Wales is influenced to a considerable extent by the configuration of the land. If the land were flat and of uniform level the only factors affecting climate would be the heat received from the sun, which would diminish uniformly from south to north, and the prevailing wind, which would blow on the whole from some point between south-west and west-south-west. The result would be that in summer, when the sun is powerful, temperature would be highest in the south and lowest in the north; and in winter, when the sun is feeble, temperature would be highest in the west where the warm air from the Atlantic exercises its full influence, and lowest in the east. The temperature would, in addition, be more extreme-hotter in summer and colder in winter-than the latitude warrants in the centre of England on account of its distance from the sea, and in the south-east on account of its proximity to the Continent. The rainfall would be nearly uniform over the whole surface of the country, although in the region of more extreme temperature it would be less on the whole, while the falls in thunderstorms would be greater.

In reality the climate varies greatly from point to point, the conditions stated above being modified in the most intricate and interesting way by the configuration of the ground. The temperature of the air falls off, as the height above sea-level increases, at the rate of $1^{\circ} \mathrm{Fahr}$. for each 300 feet, so that places on the high moorlands rising to 1500 feet or more are permanently, and at all seasons, at least $5^{\circ}$ colder than places in the same latitude at sea-level. Where the land slopes towards the south, the rays of the sun fall more nearly perpendicularly on the surface, and their heating power is consequently greater; while where the land slopes towards the north, the rays fall more obliquely, and the heating power is less than on level ground; hence local climates of very different character exist in places which are in the same latitude and have the same height above the sea. The wind, though it usually blows from some westorly or southerly point and is relatively warm, frequently comes from northerly or easterly directions and is cold; and it necessarily happens that places on the east coast, or on the eastern side of high masses of land, are more exposed to harsh 
and inclement weather than those on the western slopes. Where a range of hills or a line of cliffs protects a favoured spot from north and east and leaves it open to south and west, the warmest climate possible to our islands is produced, though it may be in a very small area, such, for example, as the sea-margin at Bournemouth and Torquay. It is to this cause rather than to their position in latitude that the mildness of the seaside towns of the south coast is due; while the sharp bracing climate of the Yorkshire coast and moors is in its turn the result of exposure to easterly and northerly winds rather than of latitude.

The effect of configuration upon climate is most marked in the case of rainfall. Moisture-laden wind may blow over a level expanse of country and produce little precipitation, but when it encounters a slope and is forced to rise into the cooler regions of the upper air condensation increases rapidly, and to a considerable extent the rainfall of the land increases with its altitude. The effect is, however, probably due to slope as well as to height, a steep hill causing the air to ascend for some time after the summit is passed, and so producing the maximum fall of rain a little distance beyond the summit on the leeward side. On account of this relationship, and because of the shelter afforded by a mass of high land to a plain to leeward, the rainfall map of England and Wales, while it corresponds very closely to the map of vertical relief, resembles a blurred impression. The famous centre of high rainfall at The Stye and Seathwaite in the Lake District, and the scarcely less wet valleys on the east of Snowdon, owe their character for intense wetness to this fact. The highest average rainfall occurs in the mountains of Wales, the Lake District, the Cheviots, and the Pennine Chain ; and to a less marked degree on the high moors of Cornwall and Devon, and along the lines of the Cotteswold and Chiltern Hills, the Chalk Downs, and the Wolds of Lincoln and York. A narrow zone of low rainfall borders the coast on the west as well as on the east, and whenever a plain stretches inland, it forms a region of low rainfall. Even a comparatively narrow valley running up amongst hills maintains a lower rainfall along its floor than prevails on the bordering heights. Shelter also plays its part, and all causes conspire to make the driest region of England the inland portion of the low Eastern Plain which extends from the Humber to the Thames. The great dry area of England stretches westward to the Severn valley, and it is surprising to find how low a mean annual rainfall prevails close under the Welsh mountains, which drain the sea wind of its moisture. It sometimes appears that the rainfall begins to diminish with altitude after a cortain height above sea-level is past; but it is more likely that the exposed position of the rain gauges on high hill-sides causes increased loss of rain on account of eddies set up by the wind about the gauge.

Vegetation is perhaps even more sensitive to variations of temperature and rainfall than to changes of soil, though in this connection 
it must be noticed that a stiff clay subsoil, as in the Fenland, may retard the drainage of low flat land to such a degree as to counteract the effects of a low rainfall and produce a humid climate nourishing a marshy vegetation. The profitable cultivation of all farm crops ceases at a comparatively low elevation, and above 1500 feet, alike in the south and in the north, the vegetation is reduced to the plant-associations typical of moorlands-heather, fern, and mosses ; trees have disappeared, and except when the moor is drained and cultivated, grass does not predominate. When the land rises to 2500 feet or over, the surface is usually of bare stones, scantily starred by a few stunted plants growing in the slight shelter between them.

Since cultivation is possible in the lower grounds only, it follows that the higher regions of the country are practically without population except where mineral resources are abundant and valuable. The highest land, though of little use even for sheep pasture, is essential to the life of the large towns of the valleys penetrating the high moorlands, and even to those of the more distant plains, for the collection of the rainfall in reservoirs for.water-supply. So great is the demand for water in large towns, that there is now scarcely an uninhabited moor or upland in the whole Pennine chain which has not been set apart for water-supply, and in most cases efforts are made to remove all possible causes of pollution by keeping the ground free from crops or live stock.

The elevation and configuration in the Eastern Division exercise no direct influence on population, as no part rises above the limits of pasture, and very little is above the zone of profitable cultivation. An indirect influence is, however, produced by the geological formation, for the hills are permeable masses of chalk, limestone, or sandstone upon which no surface water is available, while the plains are covered with stiff clay, through which the water-bearing rocks may be reached at no great depth. Hence in the Eastern Division also the hill ridges, though often traversed for long distances by high-roads, are devoid of population, which throngs densely on the low ground. The Lincoln Edge, the Chiltern Hills, and in an even more interesting way the Weald, supply excellent illustrations of this fact.

Speaking broadly, and of course excepting seaports, the geological rather than the hypsographical map explains the distribution of population in England and Wales. Wherever mineral wealth or easily reached underground water is found, there are towns or close chains of villages; where neither is to be had, there are strips of country, even within 50 miles of London, which are totally uninhabited. It must be noted, however, that when it is possible to sink deep wells, or when it becomes profitable to pump a supply of water from a distance, as in the parts of the North Downs nearest London, modern residences have sprung up in large numbers, an accessible water-supply having been the one thing lacking for a dense population. 
The Western Division.-The Cheviots form the most northerly mass of high land in England; the northern part, indeed, belongs to the Southern Uplands of Scotland. The Cheviots are grassy hills furnishing excellent pasturage for sheep, and giving rise to numerous rivers which flow to the North Sea, a number of south-flowing tributaries uniting in the Tyne, the narrow valley of which is joined by the Tyne Gap to a valley draining to the Solway, and the two completely isolate the Cheviots from the Pennine Chain. Through this gap runs the direct railway between Carlisle and Newcastle, and along its northern slope the Romans built their great wall against the Caledonians.

The Pennine Chain runs southward from the Tyne Gap as a broad moorland, loftiest on the western side, where it rises in summits of nearly 3000 feet, and sending rivers towards the east through long dales, the home of the sparse pastoral population of former days. In the Crossfell section the Lower Carboniferous rocks of the high moorlands give place upon the eastern flanks to the Coal Measures, and the lower valleys are the site of a dense coal-mining and iron-manufacturing population, the outlet for whose industry is through the seaports of the Tyne, Wear, and Tees. Crossfell itself is the culminating summit of the remarkably steep and straight escarpment which bounds the Eden Valley and faces the gentler heights of the Lake District, forming the nearest approach to the appearance of a mountain range in England.

The Whernside section of the Northern Pennines extends as a more broken and broader mountainous group from the valley of the Greta, a tributary of the Tees, to the Aire Gap, where the valleys of the Aire and the Ribble nearly meet. On the west it closely adjoins the Lake District; on the east its long dales widen as they descend between spurs of moorland to the broad Vale of York. Health and pleasure resorts, such as Harrogate and Ilkley, have arisen to take advantage of the fine air of the moors, the climate being in some instances the most valuable of the natural advantages.

Southward from the Aire Gap the Pennine Chain contracts in breadth, and the Southern Pennines, after rising to 2088 feet in the wild limestone plateau of Kinderscout in the High Peak District, subsides southwards in a series of radiating spurs separated by the romantic river valleys of Derbyshire. This section of the Pennine Chain is the most remarkable of the three. The Coal Measures crop out both on the eastern and the western slopes, giving to both sides of the country the character of mining and manufacturing districts. Chains of towns of every size run through the lower valleys. Some of these are mere aggregates of mean houses, sheltering miners and factory hands, stretched for dreary miles along the wind-swept upland valleys ; others are great cities on the plain. Manchester and Oldham, with their satellite towns, stretch almost to Liverpool over the Cheshire Plain on the west 
Leeds, Bradford, and Sheffield cling closer to the hills on the east, and form, with other woollen-weaving towns of the West Riding, a zone of seething urban life between the desolate uplands west of them and the quiet agricultural Vale of York to the east. Almost every valley in this section has its railway, and several are traversed by canals. The lofty ridge separating Lancashire from Yorkshire is surmounted by chains of locks on the canals, crossed at the passes by several railways, and pierced by others in tunnels several miles in length. It is one of the most striking instances in the geography of the British Isles of a natural barrier of a somewhat formidable kind overcome at the command of trade necessity. Sheep are still pastured on the slope of the moors, though practically all the wool employed in the manufactures is now imported. In some of the remoter valleys semi-domestic industries, especially paper-making on a small scale, still linger, the motive-power being supplied by water; but the coal-mines now determine the sites of all important manufacturing towns.

As in most regions of pronounced onfiguration, the boundaries of political divisions in the Pennine Chain follow natural features. The watershed running from north to south forms, with scarcely an exception, the county boundaries between Cumberland, Westmorland, and Lancashire on the one side, and Northumberland, Durham, and Yorkshire on the other. The boundary between Durham and Yorkshire is marked throughout by the river Tees; though usually the dales forming the valleys of the rivers are natural units, in which the old spirit of the clannish pride and perhaps the local jealousy of dalesmen of former days may sometimes still be traced.

The Lake District is a remarkable mountainous region separated from the Pennine Chain by Shap Fell and the divergent rivers Eden and Lune. It is scored radially by a series of valleys of remarkable beauty, most of them containing one or two long narrow lakes of considerable depth. Here practically all the natural lakes of England are comprised within a circle of 15 miles radius. The region rejoices in an excessive rainfall, due to its abrupt ascent in the track of the prevailing sea wind, and it is of little economic value save in the coastal plain, where there are coal mines and seaports. Its few inhabitants depend for their livelihood mainly on the tourists attracted by the beauty of its scenery and on the well-to-do residents to whom its literary associations make it a congenial home. The whole district is full of charm, for the beauty of a dry day in a land of rain amply repays the patience with which it may sometimes be awaited.

Two other small hill-groups, not unlike miniature Lake Districts devoid of lakes, separate themselves westward from the Pennine Chain and spread out into the Cheshire Plain. These have no comprehensive names sanctioned by local custom, but they may be called after the ancient forests of Bowland and of Rossendale. 
They are now clusters of barren hills separated by valleys-the Bowland Forest group only silent pasture, the Rossendale crowded with small towns of factory workers and miners, with the great centres of Bolton, Bury, and Rochdale on the south, and Blackburn and Burnley on the north. Both groups are diversified by artificial sheets of water in the reservoirs, some of which rival natural lakes in size.

The peninsula of Cornwall and Devon has a distinct individuality amongst the natural regions of England. Its separation from the Eastern Division is accentuated by the small plains of Somerset and of the Exe, to the west of which rise the typical moorland masses of Exmoor on the north and Dartmoor on the south, separated by the Plain of Devon. These moors are desolate and dreary in the extreme, the last haunt of the wild red deer, and no more hopeless hold for prisoners of war could well be imagined than the huge building on Dartmoor, erected during the Napoleonic struggle and now the most forbidding convict prison in the country. The heights in Cornwall are less pronounced, but Bodmin Moor is a fitting companion to the moors of Devon, and the precipitous cliffs of the coast, veined with ores of copper and tin, afford an indication of the resources which made Cornwall a place of importance for centuries, and at one time, now many sears ago, a leading centre of original scientific work.

Wales acquires its semi-independent position as an integral part of South Britain from historical considerations; but these are direct consequences of its position and configuration. Physically the Welsh Highlands include the hills of Shropshire, Hereford, and Gloucester west of the Severn, as well as the county of Monmouth, which is grouped for all practical purposes, and especially for statistics, along with Wales, though actually part of England. Although the Shropshire hills are of no great height, they are picturesque and prominent features, and stand in close agreement with the geological structure. The Malvern Hills rise in the Vale of Severn much as Charnwood Forest rises above the plain of the red rocks in the north of the Midlands.

The loftiest and most picturesque of the Welsh mountains are those of the north-west, which rise in two distinct divisions. Of these the Snowdonian group culminates at 3560 feet in Snowdon, the loftiest mountain south of the Scottish Highlands. Its flanks are trenched by valleys, in many of which small lakes or tarns still remain. The whole group of Snowdonia has a very high rainfall on account of the abruptness with which the mountain slopes rise from the level of the sea, fronting the wet west wind. This, with the centre of the Lake. District and a portion of the North-Western Highlands of Scotland, can claim the distinction of being one of the few spots in Europe with a mean annual rainfall exceeding 100 inches. The industry of the district lies mainly in the great slate quarries; but the coast is lined 
by health resorts, of which Llandudno, by reason of its sheltered situation and mild, dry climate, is the chief. To the south and east, beyond the valley of the Dee, which contains Bala Lake, the largest natural body of fresh water in Wales, the Berwyn Mountains form another belt of high ground running nearly at right angles to the trend of Snowdonia. While the steep north-western face of the mountain group drains through the Dee to the Mersey, the gentler south-eastern slopes discharge the copious rainfall through long valleys to the Severn. In one of these a great reservoir-Lake Vyrnwy, as large as Coniston Water-has been constructed for the supply of water to Liverpool. The great reservoir has a special geographical interest, for it has been formed by reconstituting an ancient lake-bed, and so restoring a feature of pre-glacial topography. This section of North Wales is for the most part uninhabited except for villages in the valleys, and the larger part of the population continue to speak no language but Welsh, so great is the isolation of the district from external intercourse.

Mid-Wales, between the valleys of the Severn and the Wye, is a rough plateau rising on the east and still higher on the west above the level of the centre. The eastern elevations culminate in Radnor Forest, the western form a nearly continuous chain, the Mynydd Bach, running at first south and then south-westward from Plynlimon. On the eastern flanks of this ridge new reservoirs for the supply of water to Birmingham have created two large and picturesque lakes in the valley of the Elan, a tributary of the Wye, one of which is as large as Bala Lake, the other inferior only to Windermere amongst the lakes of South Britain. This western ridge is not crossed by a railway for nearly 60 miles, and it has formed an almost complete barrier to communication between east and west.

The South Wales uplands are separated from those of the north by the Vale of Brecon, through which the Usk flows south-eastward. They culminate in the Brecon Beacons, the slopes leading up to which from the south are deeply scored by parallel valleys of southward drainage cutting through the Coal Measures, and consequently the scene of enormous activity in coal-mining and iron-smelting. All the principal valleys, and many steep and difficult gorges, are traversed by railways linking the mines and blast-furnaces with Swansea, Cardiff, Barry, and Newport, the ports of shipment on the coast of the Plain of Gwent. This region acquires imperial importance from its mines of anthracite, the smokeless coal which is peculiarly adapted for the furnaces of warships. The dense populations of the narrow valleys are still so recent that they have hardly given rise to any towns; even Merthyr Tydvil is in plan and appearance scarcely more than an overgrown village, though it houses over 100,000 inhabitants. Barry Dock was excavated in 1888 amongst the sand-dunes on a desolate piece of coast, in order to 
afford a new outlet from the coal-fields of the high valleys to the sea, and within a few years it ranked as one of the great seaports of the world.

The compact group of the Black Mountain between the Usk and the Wye is a wild and desolate district, though on the margin of the fruitful plain of Hereford.

The Midlands.-The plain which surrounds the southern extremity of the Pennine Chain, separating it from the Midlands on the south, and from Wales on the south-west, is deepened into the Vale of Trent trending east and north, and the Cheshire Plain trending west and north. South of these slight depressions the Midlands rise to an undulating plain some hundreds of feet above sea-level. For the most part this district is formed of the Triassic red rocks, through which coal may be reached in many places, and so there have arisen, not only the great commercial centre of Manchester, but also the vast industrial aggregations of population in the Potteries about Stoke and Hanley, and in the Black Country to the north and west of Birmingham. The development of the mineral wealth of the Black Country has a somewhat remarkable history, for when the old ironworks deserted the forests of southern and eastern England on pit-coal taking the place of charcoal in smelting, coal-pits were at hand to supply the ironworks, near Birmingham, which formerly drew their supplies of charcual from the Forest of Arden. The Midlands are diversified by hills of ancient rock rising like islands through the newer strata of the plain. Of these the most remarkable are Charnwood Forest to the north-east and the Wrekin to the north-west. 'The Vale of Severn separates this region on the west from Wales, and forms a region peculiarly favoured by soil and climate, for it combines the warmth of the west with the dryness of the east.

The Eastern Division.-The physical character of the Eastern Division can be understood best when the geological map is superimposed upon that of configuration.

The predominant features are the long lines of low hills of limestone or chalk rising with a steep face on one side, usually the north or west, above a plain of clay, and sinking with a gentle slope to the opposite side, usually the south or east, beneath a plain of clay similar to the first, so far as appearance is concerned, but of more recent origin geologically.

The line of limestone hills, forming the Oolitic escarpment of the geologists, commences with the Cotteswolds, which, attaining a maximum height of 1000 feet, run with a curved front along the eastern margin of the Vale of Severn, and the southern margin of the Vale of Evesham. The hills are tunnelled by several lines of railway on their way from London to the west of England, and crossed by one line of the Great Western, as well as a canal, winding through

No. VI.-December, 1904.] 
the Gap of Stroud. The pasturage on these hills supplied wool in old days for a spinning and weaving trade, which still survives in the production of West of England cloth. The line of the Cotteswolds is continued in Edge Hill, and further to the north in the less pronounced ridges of Northamptonshire; but even where the escarpment fades into the low Lincoln Edge or a mere cliff along the right bank of the Trent, it remains a distinct feature in the landscape. Beyond the Humber the limestone hills reappear, bounding the Vale of York, on the east, and rising in the North York moors and the Cleveland Hills to just over 1000 feet. In the Cleveland Hills overlooking the estuary of the Tees valuable ores of iron occur, and have been the determining cause of the great iron industry which gave rise to Middlesbrough. The plain of Lias clay at the base of the Oolitic escarpment forms the rich agricultural belt of the Midlands, with Leicester as its most important town, and the beautiful sylvan scenery of the "Dukeries," perhaps the most typically English landscape in the country. The number of ancient towns, of no great size, but with historic names which belong to this belt of country, is worthy of note, and points to a time when the conditions determining the distribution and growth of centres of population were totally different from those now in force. The quiet old cathedral cities and market towns flourished in full activity when the Church had a monopoly of learning and the farmer a monopoly of trade, and they naturally failed to expand with the growth of manufactures carried on by means of mechanical power.

The northern line of Chalk hills rises in turn over a rich agricultural plain of clay, under which the gentle slopes of the Limestone hills dip, and forms a series of bare and rounded heights without inhabitants, and valuable only for pasture. They run through Dorset as the Western and the Purbeck Downs, form the northern edge of Salisbury Plain, and then the short chain of the White Horse Downs leading to the central portion known as the Chiltern Hills, which sink northeastward into the East Anglian Ridge, reappear again beyond the Wash in the Lincoln Wolds, and beyond the Humber in the Yorkshire Wolds, which end grandly in the white chalk cliff of Flamborough Head. On the clays and water-bearing Greensands at the base of the Chalk escarpment there is almost everywhere a line of villages and small towns where the scanty population of purely pastoral and agricultural parishes is concentrated. The continuity of the Chalk hills is more geological than geographical; at their highest they are completely cut through by rivers, as in the Thames Gap below Oxford, which draws a natural line between the Upper Thames Basin, formed by converging valleys on the long slope of the Cotteswolds, and the Lower Thames Valley, which lies on the London Clay. Towards the east the Chilterns sink to a mere ridge on the great Eastern Plain, which sweeps through the east of England from the estuary of the Thames to the Vale of York. 
The Eastern Plain is lowest in its central portion around the shallow Wash, where it forms the almost Dutch district of the Fenland, a sort of saucer of clay filled with a nearly level sheet of silt and peat. Some of it is below mean tide level. Much of it has been artificially drained and embanked, and wherever a bed of gravel or some portion of the underlying rocks penetrates the surface and rises more than 25 feet above the sea, it forms the site of an ancient town clustered picturesquely round a still more ancient church. Ely with its cathedral is the finest type of a purely Fenland city.

The lower Thames valley occupies a hollow in the Chalk filled with clay and gravel, and its low level and gentle slope allows the tidal influence to extend a very long distance from the sea. Here at the head of ocean navigation, the vast conglomerate of municipalities known collectively as London has arisen and is steadily extending on every side, in complete disregard of natural conditions, for proximity to London makes a marsh or a steep hillside equally worth reclamation or terracing into building sites. The geological formation secures a vast natural water-supply in the saturated Chalk lying below the impermeable layers of clay. Artesian wells bored through the clay tap this supply, which is derived from the ring of Chalk hills surrounding London at a distance still beyond the suburban area; but year by year the wells have to be deepened to keep pace with the ever-sinking level of saturation. Thus it has come about that every natural condition which favoured the original foundation and early growth of the capital of the British Empire has ceased to exercise any influence upon it, and London grows now because the demands of centralized national life require it to grow from the centre that has been fixed by immemorial custom.

South of the Lower Thames Valley the district of the Weald occupies the south-eastern corner of England. The Hampshire Downs, running eastward from Salisbury Plain, divide and proceed as the North Downs and the South Downs to the sea at Dover and Beachy Head respectively. The steep faces of these two lines of Chalk hills look towards each other across the clay-covered plains of Kent and Sussex, separated by the sandstone upland of the Forest Ridges. The northern slope of the North Downs dips below the clay of the Lower Thames Valley, the gentle slope of the South Downs dips similarly below the similar clay of the Plain of Selsey. The rivers rising in the Forest Ridges breach the Chalk ring of the Downs at numerous points, each gap permitting the passage of roads and railways, and each an important strategio point which must be protected in any seheme for the defence of London. The Downs until recently were totally uninhabited ranges of sheep pasture, and though they are now being built upon as the healthiest spots in the immediate neighbourhood of London, the ancient chain of small towns and villages built on the narrow terrace of the Upper 
Greensand between the Chalk and the clay remains to attest the harmony established between the village organism and its envirorment in the days of normal development, before the external attractions of London dwarfed all other considerations.

\section{THE FULANI EMIRATES OF NORTHERN NIGERIA.}

By Major J. A. BURDON, F.R.G.S., Resident of the Sokoto Province.

BEFORE turning to the special subject with which this paper deals, namely the Fulani emirates of Northern Nigeria, I think I ought to say a few words on Nigeria as a whole, in order to show why my remarks are confined to one particular district, and to prevent the idea that the description which I shall give is applicable to the whole of Nigeria, or even to the whole of the Northern Protectorate.

Nigeria, an English-made name given for convenience to the British protected territory, the principal feature of which is the lower Niger river, is divided into two Protectorates by a line running east and west at about the 7th parallel of latitude. This line very nearly coincides with a natural boundary - that between the open bush and grasslands of Northern Nigeria and the dense forest of Southern Nigeria. The division is, of course, not as abrupt as such a line would imply. From the Sahara southwards to the coast there is a gradual change in every condition, the central pivot of the change being the increase in rainfall. The sandy plains of the north with their stunted thorn bushes gradually merge into rich soil with a prolific undergrowth and trees of varying value; this grows into the luxuriant vegetation of the dense lowlying forest, with its wealth of timber, rubber, and oils; and this again loses itself in the mangrove swamps of the Niger Delta.

As with climate and nature, so with man. From the light-coloured, straight-featured Fulani, one passes through many gradations to the typical negro of the coast. 'The characters of the two types are as different as their looks. Ethnology teaches us the effect of environment on race, and it is therefore easy to unders'and why the forest and swamp-dwellers of the south should be of a lower type than the inhabitants of the open northern plains. But history tells of the southward movement of superior races from the north, and it seems probable that this pressure has forced coastwards inferior aboriginal plain-dwellers. Whatever be the cause, the important point to remember is the very great difference which exists, both in character and appearance, between the inhabitants of the northern plateau and the natives of the southern forests.

England pictures West Africa as peopled by " niggers," by the type 


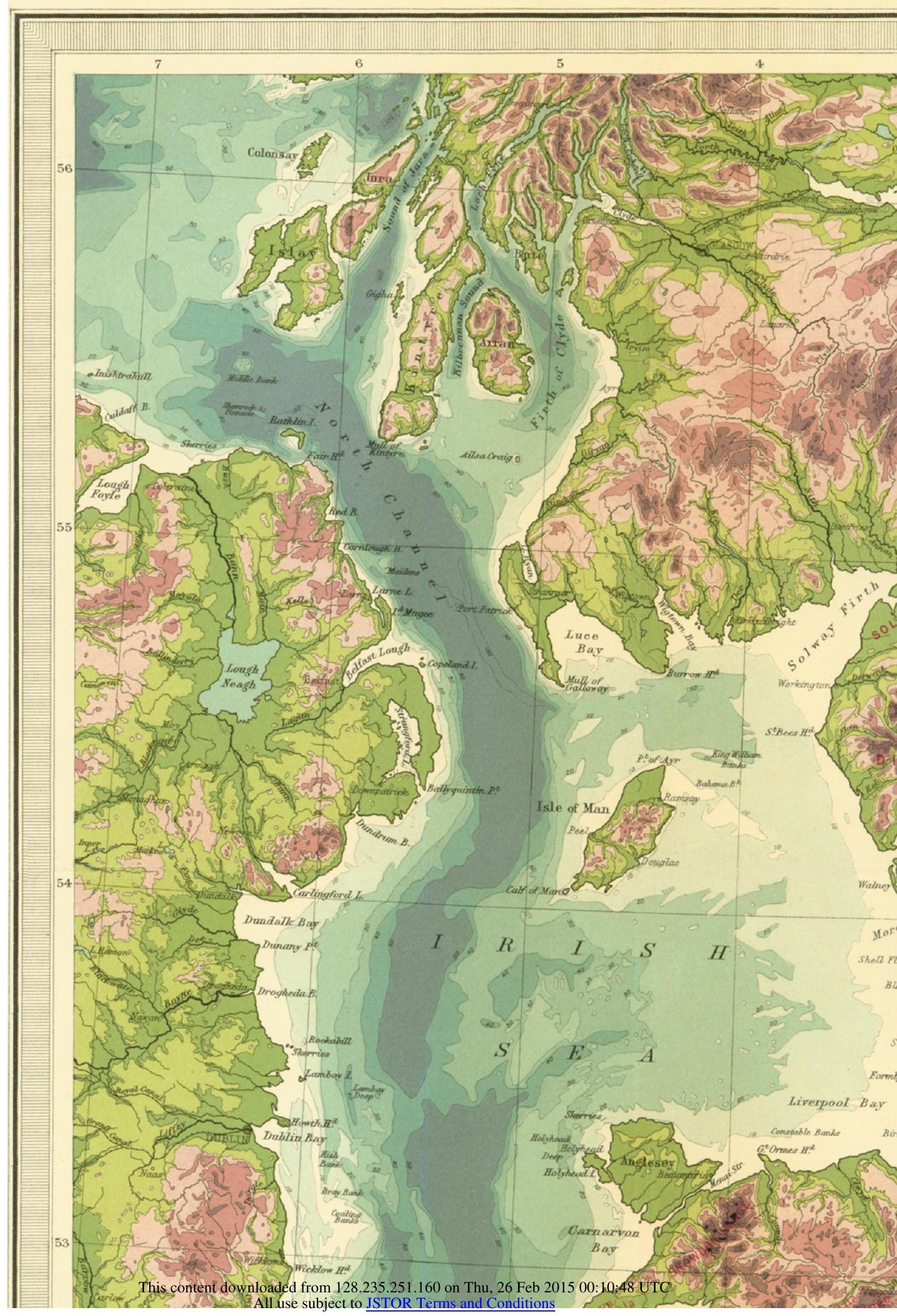



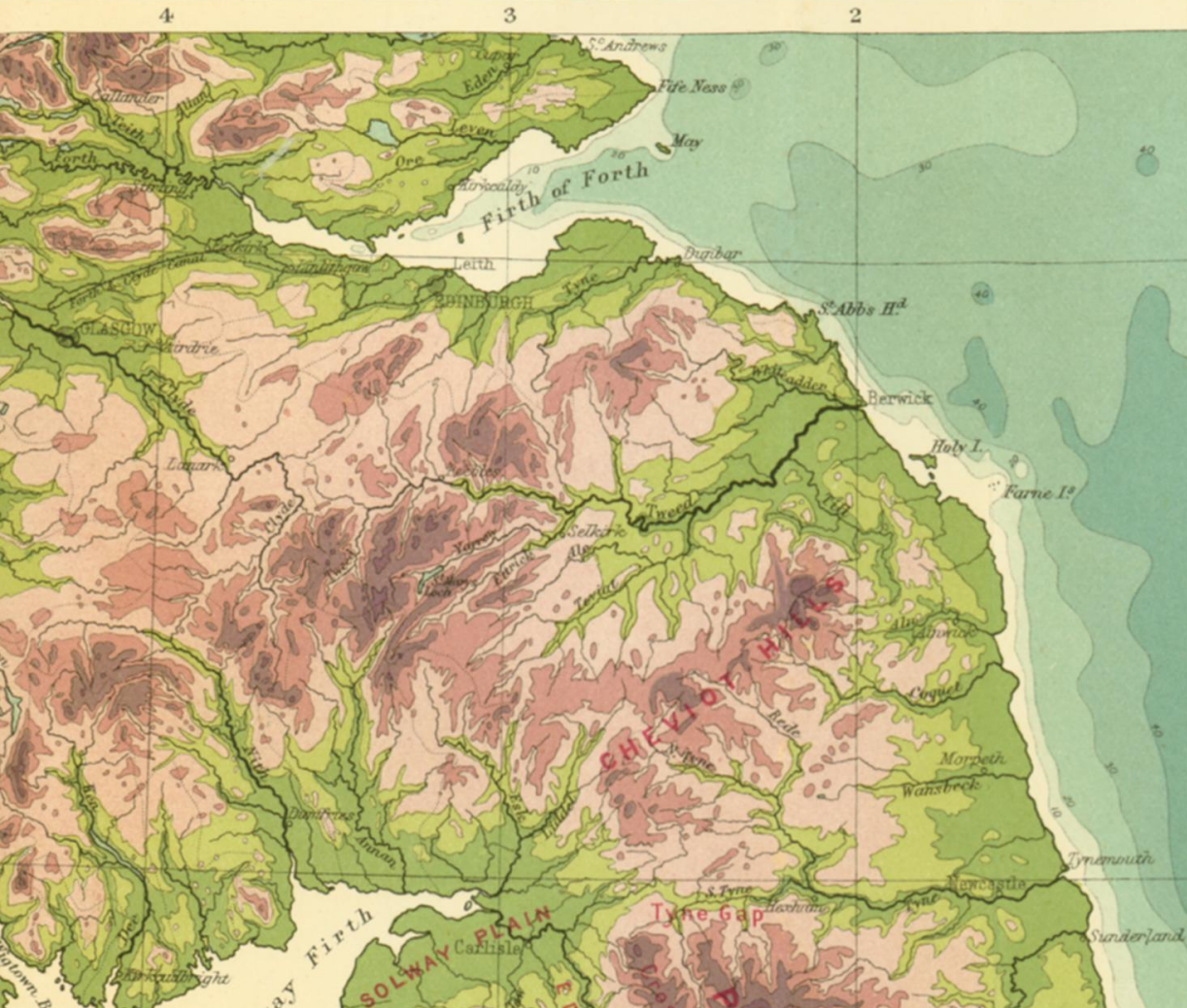

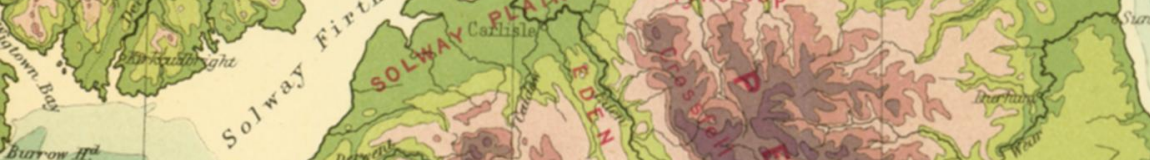

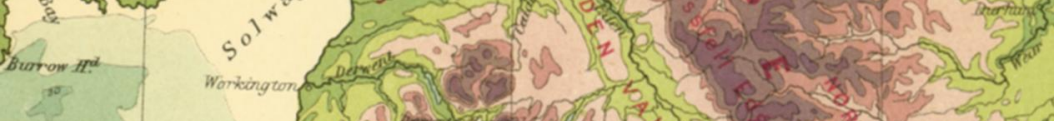


1

2

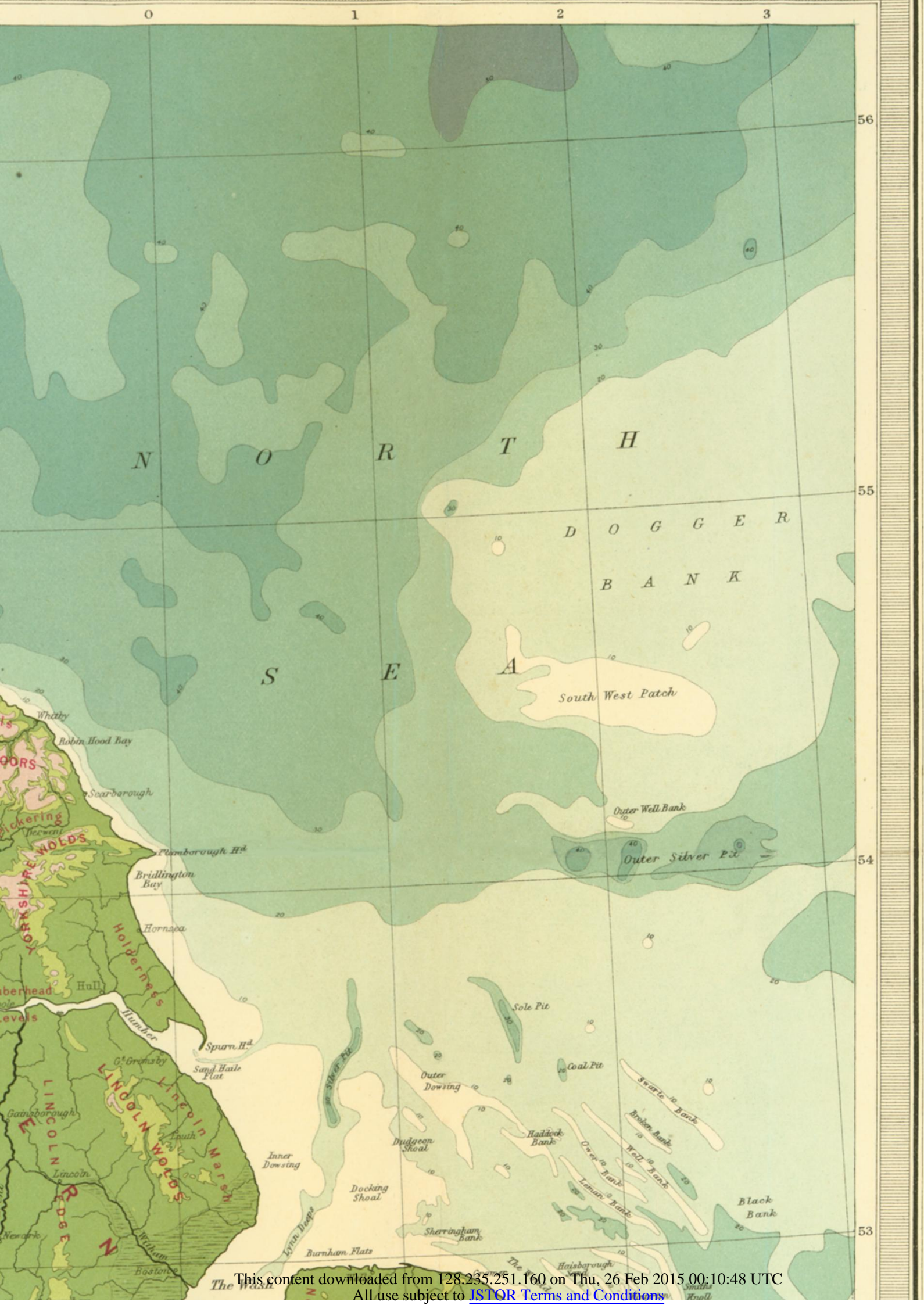




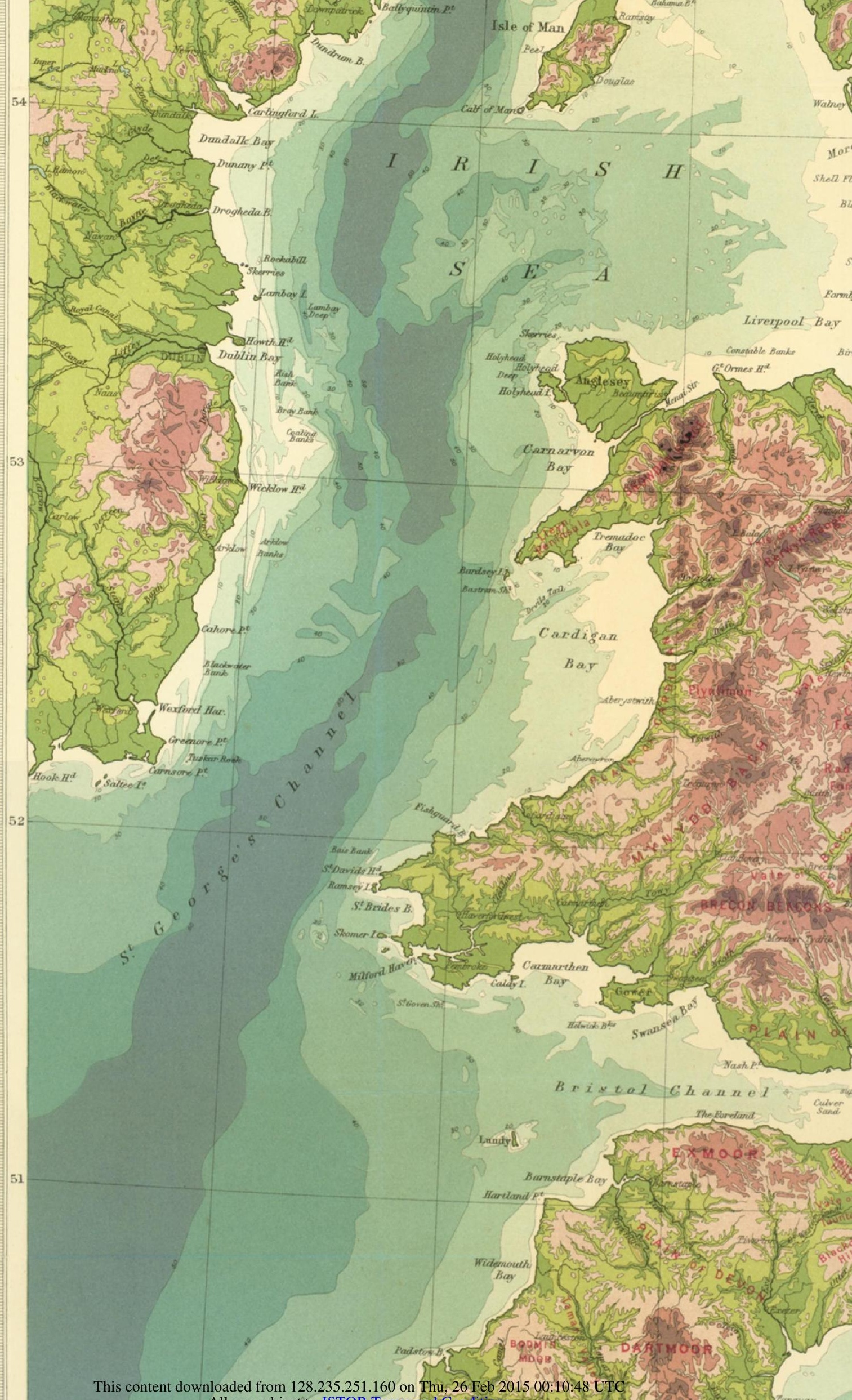

This content downloaded from 128.235 .251 .160 on Thu, 26 Feb 2015 00:10:48 UTC
All use subject to JSTOR Terms and Conditions 



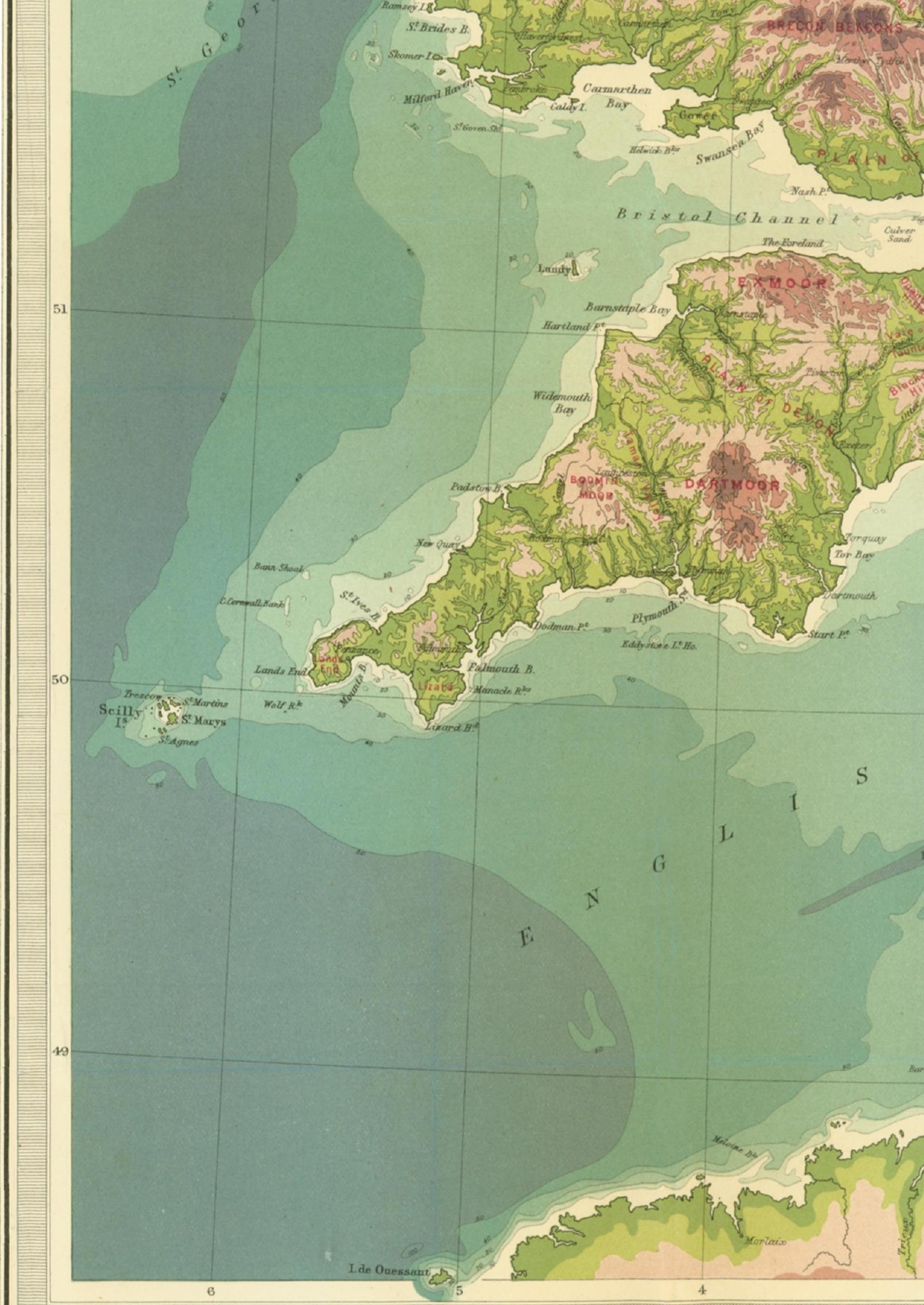

6 


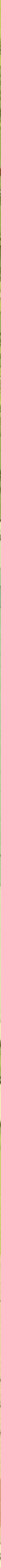




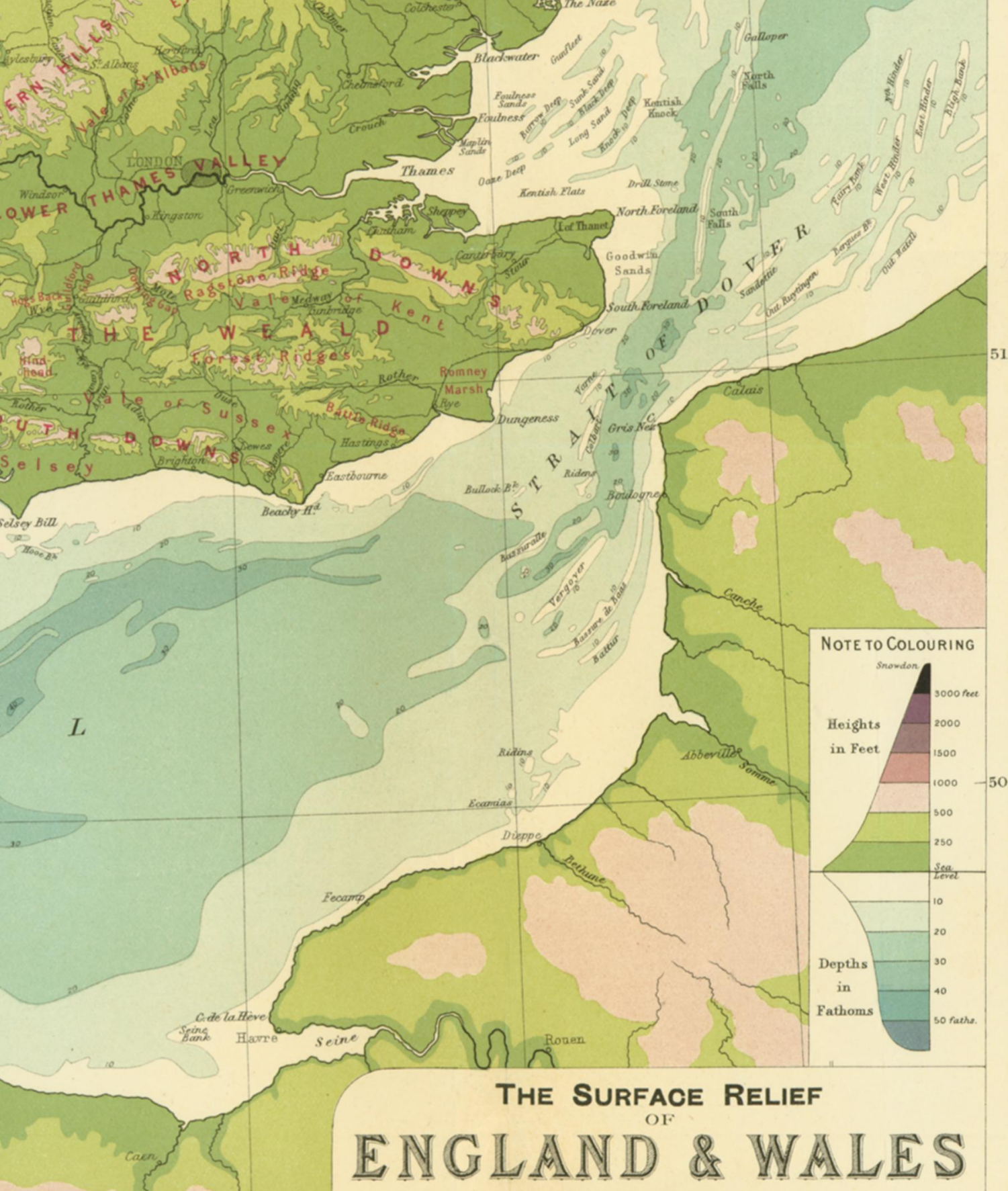

Reduced by permission from the

Ordnance Survey and Admiralty Charts

BY J. G. BARTHOLOMEW.

\section{With a Systematic Nomenclature of the Orographical Features}

Edited by H. R. Mill, H. J. Mackinder, and G. G. Chisholm, and approved by the Council of the Royal Geographical Society 